This item was submitted to Loughborough's Research Repository by the author.

Items in Figshare are protected by copyright, with all rights reserved, unless otherwise indicated.

\title{
Labouring the Point: Operation Victory and the Battle for the Second Term
}

PLEASE CITE THE PUBLISHED VERSION

PUBLISHER

(C) Elsevier

LICENCE

CC BY-NC-ND 4.0

REPOSITORY RECORD

Wring, Dominic. 2019. "Labouring the Point: Operation Victory and the Battle for the Second Term". figshare. https://hdl.handle.net/2134/1084. 
This item was submitted to Loughborough's Institutional Repository by the author and is made available under the following Creative Commons Licence conditions.

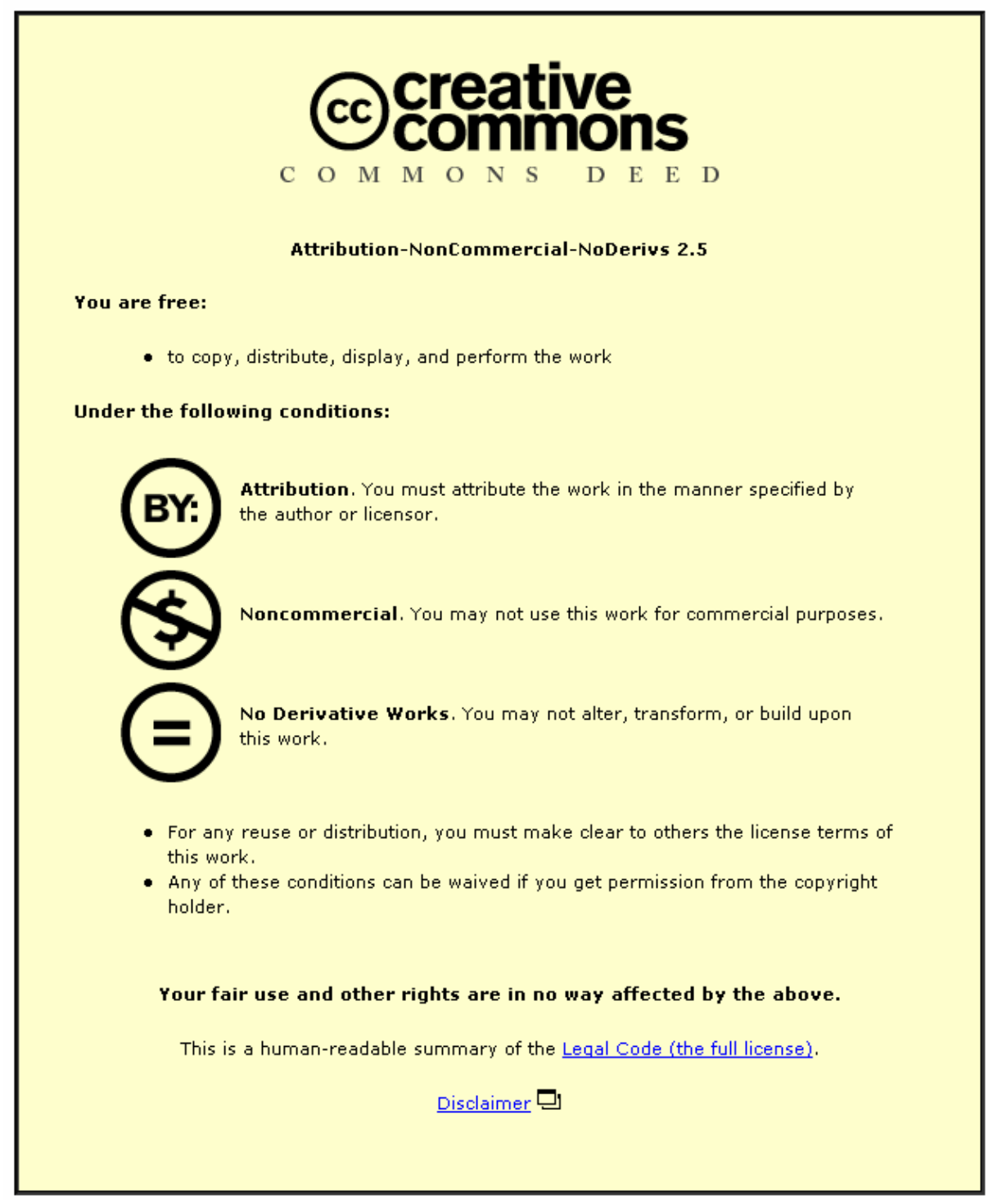

For the full text of this licence, please go to: http://creativecommons.org/licenses/by-nc-nd/2.5/ 


\section{Loughborough University}

Dominic Wring

'Labouring the Point: Operation Victory and the Battle for a Second Term.'

Journal of Marketing Management Special Issue on the General Election. 2001 Vol 17, 9/10 


\section{Abstract:}

Labour's second landslide victory of 2001 seemed inevitable given the almost continuous public support for the government through its first term. This paper considers the ways in which the party attempted to maintain and cultivate the electorate's backing during the last four weeks or 'short' campaign. Perhaps fearing apathy more than the Conservatives Labour launched 'Operation Turnout' in order to mobilise its core supporters. Though this attempt failed to boost electoral participation the party nevertheless achieved another major victory. In this so-called 'apathetic landslide' Labour was able to strategically outmanoeuvre their principal opponents the Conservatives. Interestingly the more telling and potentially compromising criticisms of government policy and party procedure came from sympathisers. These and other points will be examined with recourse to a marketing analysis of the Labour campaign.

Author: Dr Dominic Wring, Department of Social Sciences, Loughborough University, Leicestershire UK LE11 3TU. E-mail: D.J.Wring@lboro.ac.uk Tel: +44 (0) 1509 228350; Fax: +44 (0) 1509223944

\section{Autobiographical note:}

Dominic Wring is Lecturer in Communication and Media Studies at the Department of Social Sciences, Loughborough University. He is particularly interested in the historical role of marketing techniques and personnel in political campaigning and has published on this subject in management and political science journals. Recently he was appointed Associate Editor of Europe for the new Journal of Political Marketing. 


\section{Introduction.}

In winning the 2001 general election Labour did better than in 1997 given it now had a four year record in office to defend. That said the party had used its first period to demonstrate its administrative competence and simultaneously maintain its lead in the public opinion polls. This together with a good economic outlook, ineffectual Conservative opposition and favourable press coverage made re-election a strong possibility. The campaign, when it began, did little alter this perception.

This paper will explore Labour's 'short' general election campaign of 2001 (i.e. the traditional four weeks of debate before polling day). Inevitably this relates to the party's earlier strategic formulations (for more on these see Seyd, 2001). This is because it is often said that Britain, like many other modern states, is now experiencing the permanent campaign. Politicians, be they in office or opposition, are constantly engaged in attempts to communicate and convince electors of the worth of their proposals as well as themselves. In doing so they draw heavily on marketing theories, techniques and personnel. The process has, for good or ill, now colonised campaigning (Wring, 1999). Consequently it is useful to apply a conventional marketing framework in analysing the dynamics of an election strategy such as Labour's in 2001.

\section{Analysing a Political Marketing Campaign.}


The political marketing process embodies four components, namely the party (or candidate) organisation, the environment it operates within, the strategy pursued, and the market competed in (for a longer discussion see Wring, 1997). On the latter Gamble contends that: 'The main components of the modern political market are three; the existence of a mass electorate; competition between two or more parties for the votes of this electorate; and a set of rules governing this competition' (Gamble,1974,p.6). In an electoral context the concept of environment involves consideration of: economic trends such as unemployment levels and consumer confidence; events of domestic or international importance; the reach and partisanship of select mass media; and the organisational competence and resources of their opponents.

In contrast to market and environmental considerations that constitute the 'givens', Hunt (1976) identifies the 'controllable' factors as the collection of strategic decisions that an organisation implements as part of its marketing programme. Together these variables are commonly known as the 'mix', a configuration that consists of the '4Ps': product, promotion, place and price. The first ' $\mathrm{P}$ ' is central to any marketing effort. In electoral terms the 'product' or offering is itself a 'mix' of variables in its own right and combines three key aspects: party image, leader image and policy commitments (Worcester 1991).

The concept of party image encompasses factors such as the organisation's record in office, recent history and unity of purpose (Harrop and Shaw 1990). 
Once a largely ignored factor in electoral research, the growing and importance of leader image has been recognised in studies into the increasing presidentialisation of British politics (Foley, 2000; Mughan, 2000). Underpinning the product is the policy platform on which an election manifesto is based. This is increasingly significant given psephological research has begun to place greater emphasis on the rational choice notion of the elector as a consumer evaluating the issues and voting for the party most in tune with individual policy preferences (Denver, 1994).

Promotions form the most obvious part of a marketing campaign. The promotional mix can be divided into two principal parts commonly referred to as 'controlled' and 'free' media. The first term covers all forms of advertising, be they poster, print or broadcast forms. In politics those responsible are often termed 'image makers'. Free media refers to the publicity which parties get through mass media coverage. Inevitably organisations have less control over this kind of exposure. Consequently strategists, not to mention the voting public, tend to view this kind of coverage as being of greater importance than advertising. This in part accounts for the rise of the ubiquitous 'spin doctors' responsible for public relations and news management functions (Franklin, 1994; Jones, 1995).

At the heart of a 'placement' or distribution strategy is a network of regional suppliers. In politics the equivalent form of organisation is the party at subnational level. It helps co-ordinate volunteer labour in order to identify and mobilise potential supporters during election campaigns (Denver and Hands 
1997). It should be noted that, precisely because it is a political marketing "mix", some of the activities that may constitute part of one variable or ' $\mathrm{P}$ ' can be found in another. In this way the methods of the distribution policy closely mirror those of a promotional strategy in that both are reliant on tools such as direct mail despite having different aims.

'Pricing', the fourth part of a conventional marketing mix, enables a commercial firm to develop a strategy that will help maintain competitiveness and profitability in the marketplace. Niffenegger (1989) justifies the electoral relevance of the pricing mix by outlining its constituent parts. These elements, relating to environmental phenomena as interpreted by the electorate, comprise voter feelings of national, economic and psychological hope or insecurity.

Depending on the audience being targeted, common economic themes include the opponents' intention to either raise tax and spending or else make sweeping budget cuts. In times of international insecurity or domestic uncertainty politicians, particularly incumbents, often stress their rivals' apparent lack of diplomacy or administrative competence. Such appeals are often couched in images which stress the need to counter what is posed as a threat to the 'national interest' from 'undesirable elements' be they at home or abroad. The other element in the pricing mix relates to the psychological cost implicit in voting. A popular feature in negative campaigns, such strategies tap unspoken prejudices about a given politician's lack of ability, judgement and trustworthiness. 
'Pricing' policy need not necessarily form a wholly negative part of the political marketing mix. It is possible to conceive of a campaign strategy that promotes the idea of a domestic 'feelgood factor' or psychological notions of 'a nation at ease with itself' in their attempt to secure re-election. Despite the fact that pricing is the least tangible aspect of a marketing strategy, it is nevertheless a useful concept that complements the other variables. Precisely because it is a 'mix', pricing can be seen to interlock and overlap with the other strategic tools, particularly those concerned with promotional and product management. Marketing can be analysed in its constituent parts but should ultimately be seen in its totality.

\section{The 'Givens': the political environment.}

An ongoing foot and mouth epidemic devastating British agriculture caused Prime Minister Tony Blair to think about delaying the widely anticipated May general election. Initially seen as a major dilemma the decision to postpone made little difference to the outcome. An undoubted rural crisis, the catastrophe blighting farming dominated headlines throughout April. The controversy over the government's handling of the problem did not, however, damage Labour's standing in the polls. On the contrary the party continued to benefit from good press coverage together with its reputation for economic competence. Labour's lead remained almost constant in a way it had throughout the parliament. By contrast the Conservatives and their leader William Hague conspicuously failed to attract little public sympathy or media 
interest (Wring, 2001). The party still appeared to be suffering the consequences of its landslide 1997 defeat.

The Conservatives' lamentable position continued despite Hague imposing his authority over the Central Office headquarters if not the parliamentary party. The leader facilitated the appointment of loyal aides Amanda Platell and Sebastian Coe to the key positions of Director of Communications and Chief of Staff. Neither had considerable experience of managing a national election campaign. Nor did their pre-campaign preparations make any significant dent in the Labour lead. Following the Prime Minister's announcement of the election, the Sun published a devastatingly stark poll suggesting the government could be re-elected with an increased majority of around 300 . Though exaggerated the story underlined the thankless task facing the Conservatives.

\section{Party Organisation: the Millbank machine.}

The party's headquarters in Millbank Tower in central London where were once again central to Labour's preparations for the election. Approximately 200 members of staff helped co-ordinate the campaign (Wintour, 2001). The hub of operations was the so-called 'war room', an open plan office layout showcased by the US Democrats in the 1992 presidential race and adopted by Labour in the run-up to the 1997 election. It was designed to break down hierarchies and allow the free flow of information between different sub-units (Gould, 1998). This was particularly important given Labour was now in 
government and required a means of co-ordinating communication between ministers and the rest of the party. Potential problems of this sort were alleviated by the fact that almost everybody involved was a veteran of the 1997 campaign and many more had experience dating back long before then.

Tony Blair as party leader was nominally head of the election operation. Given Blair was also the main campaigner he was unable to personally manage and oversee the campaign. That said his authority within the party was such that he was able to delegate decision-making duties to a number of his close aides and colleagues. The most senior of these people, the Chancellor Gordon Brown, acted as Chair of Election Strategy. He oversaw the development of the so-called 'war book', the document containing all the party's plans and preparations for the campaign. Brown had undertaken this role in the 1997 election. That experience obviously proved as useful as Labour's huge lead in the opinion polls was reassuring.

Reflecting on the creative tension within their relationship, the Sun newspaper perhaps ominously described Blair and Brown as the 'Lennon and McCartney' of British politics. Nonetheless the absence from the campaign of Peter Mandelson, formerly the Prime Minister's closest adviser and a rival of Brown, removed a potential source of conflict between the two men. The MP for Hartlepool had previously served as Campaign Co-ordinator in 1997 and was expected to play a major role this time. His two ministerial resignations made his position untenable and his duties were given to Douglas Alexander. Alexander, a Scottish MP and ally of Brown, had previously helped manage 
the party's first post-devolution election effort north of the border. Other politicians with significant roles included Deputy Prime Minister John Prescott spearheaded his own tour of the regions.

While there was a large degree of continuity in the parliamentary leadership, headquarters had seen some major changes in personnel since the 1997 victory. Many involved in that campaign either went into government or lobbying jobs. Most significantly Tom Sawyer, the party's General Secretary and in effect its chief executive, departed for a seat in the Lords. He was replaced by Margaret McDonagh, the official who had co-ordinated the successful 1997 key marginal seats' strategy. In post McDonagh managed and oversaw practical preparations for the campaign. Former BBC political correspondent and Downing Street press officer Lance Price switched to Millbank where he became Director of Communications with responsibility for co-ordinating media relations. Working alongside him was Spencer Livermore, head of the so-called Rapid Rebuttal IT system purposefully designed to answer and deflect opposition attacks. They played key roles as did Greg Cook, the official responsible for the collation and monitoring of opinion research data.

Besides the politicians and permanent officials, the Millbank operation also drew on the expertise of other professionals. The Prime Minister's Press Secretary Alastair Campbell spent some of the campaign at headquarters as did other Downing Street colleagues like Pat McFadden. Labour's long time marketing consultant and Blair's polling adviser Philip Gould once again 
supervised a programme of qualitative research in the form of focus groups. Other veterans of previous campaigns such as lobbyists David Hill and Colin Byrne helped with the party's public relations efforts. The party's advertising account was awarded to the agency TBWA. It obviously helped that one of the firm's senior executives was Trevor Beattie, a longstanding Labour sympathiser and high profile figure within the industry.

Given Blair's close relationship with the Clinton administration and Millbank's adoption of the Democrats' 'war room' it was not a surprise that, once again, the party took soundings from various American political consultants. Gould, for instance, worked with fellow polling expert Stan Greenberg (Freedland, 2001). Other key Clinton aides like James Carville and Sidney Blumenthal were also reported to have been involved. Clearly these were the people who might be able to help Labour understand the lessons of the highly dramatic presidential race of 2000 . 


\section{The 'Controllables': policy positioning.}

Labour's manifesto 'Ambitions for Britain' signalled the government's desire to continue what its first term had begun. The document did, however, recognise the challenge of reviewing the management and delivery of core public services. Labour proposed to remedy this through so-called public private partnerships. Here they envisaged the involvement of private companies would help revitalise the provision of a range of services. These included the highly sensitive and salient topics of health and education.

Labour made public its key priorities by once again adopting the five pledge format from its 1997 campaign. Each commitment helps identify key aspects of the party brand and whom it saw as its main target audiences. With the exception of the last, all could be regarded as belonging to 'middle England', a code for aspirational middle-class homeowners living in the English suburbs of the south and midlands. The first pledge on mortgages, inflation and sound public finances reflected Gordon Brown's well known pre-occupation with market friendly policies. Perhaps aware of Al Gore's perceived inability to capitalise on the Democrats' record during the recent US presidential race, Labour were in effect adopting the Clintonite mantra 'It's the Economy, Stupid' by promoting the government's financial prudence. Another target was City opinion; it was courted with a special manifesto for business. In 2001 this strategy appeared to have results when the Economist magazine offered its support for Blair as the only 'credible conservative' and The Times endorsed Labour for the first time in its history because the government was 'consolidating' the Thatcher legacy. 
By contrast with the pledge on economic management, the commitment to maintain winter fuel payments for pensioners and the minimum wage was the only one to explicitly appeal to those in poverty or in danger of being socially excluded. The other three promises addressed the problems of public services by committing resources to the recruitment of thousands of extra nurses, doctors, police officers and teachers. The pledge on education also referred to improving school standards and, like the others, was clearly aimed at those families heavily reliant on public service provision. This and other related themes were revisited in Your Family, a women's magazine styled publication which used celebrities to promote government achievements. This and other publicity material highlighted Labour positioning on what strategist Douglas Alexander claimed were the party's key campaign issues of pensions, education and health (Freedland, 2001).

The Conservatives faced a key difficulty in responding to Labour on public services as they broadly agreed on the need for greater private sector involvement within the sector. There were differences in policy but these nuances were difficult to explain to an apparently disengaged public. By contrast prominent Labour sympathisers such as Mirror columnist Paul Routledge attacked the plans for ushering in the 'invasion of private profit'. Practical electoral opposition to these proposals came from smaller parties as well as the Kidderminster based Health Concern group whose independent candidate actually managed to unseat a minister and win the local Wyre Forest constituency. 
Other possible campaign issues like support for the proposed US Nuclear Missile Defence were neutralised by bipartisanship combined with deft manoeuvres by government spokespeople. The same could be said of the Dome, a project instigated by the previous Conservative government. Douglas Alexander summarised the Conservatives' positioning as being based around the issues of asylum, tax cuts and the Euro (Freedland, 2001; see also Gould, 2001). These were the essence of a pricing strategy aimed at exploiting prejudice within the national psyche and appealing to more base economic motives. The Conservative approach appeared to have limited resonance with the electorate. Labour did its best to ensure this remained the case. Most obviously the thorny issue of the Single European Currency, on which the government was perceived to be out of touch with public opinion, was largely neutralised by the renewed commitment to have a referendum before any possible British entry.

The effective 'non-decision' on the Euro underlined the marketing driven nature of Labour's strategic thinking. Despite reportedly wanting further European integration Blair was careful not to expose himself on this matter, even publicising his promise not to 'bounce' Britain into the Single Currency in the best selling daily and highly sceptical Sun newspaper. Conservative claims that any subsequent referendum would involve a rigged question smacked of desperation given the relative simplicity of this yes/no issue. Hague's subsequent decision to campaign to 'Save the Pound' was perhaps churlish and ultimately futile. 
Like the Euro the Conservatives' attempt to capitalise on the asylum debate brought little apparent electoral reward. Labour politicians, notably Home Secretary Jack Straw, had long responded with authoritarian rhetoric and policies on this particular topic. Indeed Conservative leader Hague's controversial pre-election speech in which he referred to Britain becoming a 'foreign land' was itself later attacked by Liberal Democrat Simon Hughes following serious race related disturbances in Oldham during the campaign. This particular inter-party dispute meant that it was more difficult for the Conservatives to make political capital at the expense of the government.

Similarly the party's commitment to reduce direct income taxes was compromised and undermined by a debate over alleged comments by Treasury spokesperson Oliver Letwin. Letwin had reportedly suggested Conservative public spending plans would probably mean something like 20 rather than the publicised 8 billion pounds worth of cuts. In the confusion Labour were resolute in restating their commitment to maintaining public spending levels. Once again the most telling criticisms of government policy came from sympathetic critics such as Ruth Lister keen to see ministers abandon their 'Middle England strategy' and consider raising taxes (Lister, 2001; and also Dilnot, 2001).

The 'Controllables': imagery. 
A major, if not most important, outcome of Labour's embrace of marketing has been the diminution of internal debate and almost total centralisation of authority within the leadership. Entering the 2001 race Millbank's objective was to present a united front to the media and electorate. Significantly the practice of constantly prefixing Labour's name with the word 'New', a key symbol of Blair's leadership, was abandoned. Interestingly a recurrent feature of the subsequent campaign was the way the image of party unity was challenged not by the Conservatives but by internal dissenters.

Most prominent of the unseemly internal disputes was the selection of former Conservative frontbencher turned Labour MP Shaun Woodward as a candidate for the predominantly working-class seat of St Helens South following the sudden retirement of Gerry Bermingham, the sitting Member. Woodward's past allegiances combined with his publicised personal wealth attracted unwelcome media scrutiny. Nominally a local issue the national party became embroiled in the selection process following a Millbank sanctioned panel's decision to omit several other well known candidates including the local council leader Marie Rimmer from the final shortlist.

Shaun Woodward's subsequent victory and the manner by which it was achieved were roundly condemned as a display of leadership 'control freakery'. This in turn led allies in the labour movement such as the Fire Brigades Union to publicly declare it would review its financial support for the party. They like ex-minister and former Blair ally Peter Kilfoyle were questioning of the party's acceptance of million pound donations from wealthy 
supporters such as Lords Hamlyn and Sainsbury. This in a climate of increased public scrutiny of political sleaze and campaign spending caps of $£ 20$ million.

In another potentially compromising development the admission by MP Mark Fisher that he had been offered a peerage to stand down just before the election raised serious doubts about the integrity of the party and its democratic propriety. The likely beneficiaries of this patronage, presumed to be Millbank endorsed candidates, were the type of people former party aide Derek Draper had in mind when he publicly attacked many Blairite parliamentarians as 'talentless careerists'. If this wasn't enough, Millbank actually sanctioned internal conflict by allowing elections for the party's National Executive Committee to go ahead. At best a distraction to a membership fighting the Conservatives, this unnecessary campaign encouraged intra-party tensions at the worst possible time of all.

Turning to leadership image, Blair was comfortably ahead of his main rival Hague in successive public opinion polls. Focus groups by Labour's marketing consultant Philip Gould had long identified the Opposition leader as a major weakness (Gould, 2001). Competitive advantage over his rival was an obvious benefit to the Prime Minister as was the fact that the increasingly popular Liberal Democrat Charles Kennedy led a party that targeted most of its efforts against the Conservatives in key marginal seats. The fact that Hague appeared in more Labour advertisements than for his own party spoke volumes about his public image. When the Conservatives tried to contrast his 
personal integrity against Blair's alleged lack of this quality they resolutely failed to convince the electorate.

Central to Blair's personal appeal was his image as a family man. It was notable that his son, Euan, made at least one appearance at a party event in support of his father. Similarly his mother, Cherie Booth, proved an active campaigner. She was also a valuable one who, unlike William Hague's partner Ffion, gave a keynote speech during the campaign. It was significant that Ms Booth's appearance to present the main honour on ITV's British Soap Awards was watched by 11 million while simultaneously a mere 2.5 million watched her husband's cross-examination on BBC1's Question Time Leadership Special. Though not political, the appearance of the Prime Minister's wife served as an obvious reminder of the Blair image for viewers who had opted to watch a non-election programme and whom, by their very nature, were a difficult but important audience of voters to reach.

\section{The 'Controllables': promotions.}

TBWA's pre-campaign advertising stressed government achievements through 'The Work Goes On' theme. This in turn had followed the 'Thank You' posters featuring perceived beneficiaries expressing their gratitude to Labour's 1997 voters for policies such as the New Deal programme. Following the announcement of the election, the campaign began to use more negative or ‘knocking' copy. The most memorable images featured William Hague. 'Just William' used a picture of Hague from the time he made his first Conservative 
conference speech when only a teenager. The image suggested a precocious schoolboy debater in the mould of comedian Harry Enfield's reviled 'Tory Boy' character.

Labour strategists were keen to suggest Hague was a clone of Margaret Thatcher (Gould, 2001). A striking advert featuring Thatcher's hairstyle superimposed on the balding leader's head amplified this attack. The image was recycled in media debates as to its appropriateness thereby guaranteeing additional coverage. Negativity also featured in classic Hollywood horror film styled posters replete with anti-Tory slogans like 'Economic Disaster II' and 'The Repossessed'. Similar ideas were incorporated into a Party Election Broadcast featuring a cinema type commercial attacking the Conservatives.

Conscious of the need to cultivate younger and first time voters Labour employed new technologies such as text messaging and the Internet. Potential supporters were targeted with slogans and a website called ' $R U$ up 4 it?'. Labour also successfully pre-publicised a PEB on government achievements by revealing the guest appearance of pop singer Geri Halliwell. Conveniently for Halliwell this exposure coincided with the release of her new record. More embarrassing was the allegation that the singer was not actually registered to vote on security grounds and would therefore not be acting upon on her stated support for Tony Blair, a politician she had previously denounced as a 'marketing man'. 
A similar controversy engulfed the final PEB featuring two celebrities from youth soap opera Hollyoaks. This unsophisticated film targeted young voters by showing the actors being thanked by various people for taking the trouble to support Labour. The message was undermined when a front page Sun story suggested one of those involved, Terri Dwyer, was unable to vote because she was 'too busy'. Labour's sure touch over 'controlled' communications had apparently deserted it. More importantly the actor's admission clearly undermined efforts to mobilise first time voters.

If some of the party's advertising caused it problems then there were also problems with the public relations side of the campaign. High profile embarrassments involving Blair, Prescott and Straw in hostile encounters with members of the public over health, country sports and police reform were to some extent unexpected. In fact the party's news management under Alastair Campbell and others dealt with each of these incidents reasonably well. That said a letter from Labour General Secretary Margaret McDonagh accusing broadcasters of colluding with protestors was ill judged; it inevitably became a topic of public debate. Similarly problematic were many of the proactive media initiatives, most notoriously the launch of the campaign by Blair in which he appeared at a school preaching to the pupils.

Following on from the poorly received campaign launch successive Labour photo-opportunities were subjected to media scrutiny. Particular criticism was made of an artificial meeting in Leamington between Blair and some supporters. This and other stunts led Blair's own constituency agent John 
Burton to question why aides were not letting the real leader campaign. Similar criticisms were made of the excessive control of party news conferences. Gordon Brown, regularly in the chair for these events, was accused of sexism following the party's persistent failure to let women politicians speak from the platform. But a more telling and forthright observation came from Chris Powell, a former party advertising adviser and Mandelson's former colleague in the 1987 and 1997 campaigns. He was clearly concerned about more than presentation:

'The concentration by the public and the media on the packaging rather than the product can only fuel a cynicism that it is all a game. Everywhere artifice, nothing natural and true to itself. This, combined with the poll-fed impression that it is in the bag, could lead to record levels of abstention' (Powell, 2001).

\section{The 'Controllables': place}

The fact that Labour designated its 2001 campaign Operation Turnout rather than something similar to the 1997 label Operation Victory reflected a central strategic concern. As one organiser admitted: 'The size of our majority will depend on a high turnout' (Wintour, 2001). From December 1999 resources were concentrated on defending the 90 key seats targeted and won at the last general election. But the main concern was that stay at home voters might cost Labour the other 66 'far side' constituencies the party unexpectedly gained in 1997 (Cook, 2001). Public recognition that there might be difficulties in mobilising the core vote came with a well publicised eve of poll visit by Blair 
to Pontefract and Castleford, Labour's fourteenth safest seat (majority of over $62 \%$ in 1997). This reflected real concern over whether the party's traditional working-class constituency would bother to participate in the election. Ironically peculiarities in the electoral system helped Labour retain just about all of these 146 'priority' seats following a slight swing to the Conservatives.

In the months leading up to the general election Millbank had made preparations for the eventual announcement of the polling date. When Blair called the election Labour strategists immediately launched a plan of action. This began with an attempt to contact around $50 \%$ of the electorate living in the battleground constituencies in order to identify potential vote switchers and doubtfuls. Central to this effort was the party's new call centre at Tyneside in the north east of England. This facility's ability to contact up to 10,000 voters each night provided Labour with a valuable means of strategic self-promotion as well as instant electoral feedback (Travis and Maguire, 2001). Similar efforts were put into organising a direct mail campaign (Seyd, 2001).

300,000 voters in over 60 battleground seats were sent professionally edited videos featuring the actor and Labour National Executive member Tony Robinson introducing the local Labour candidate together with sympathisers talking about themselves and their community (Denver et al., 2001). Another key aspect of local efforts were blitz canvasses in which Labour MPs limited their time with each household to 30 seconds in order to maximise exposure. 
Labour's attention to detail was remarked upon by a number of those national journalists on the Blair battlebus. Acknowledging the potential importance of regional press and broadcasting networks, the Labour press machine developed a strong sub-national PR effort and took care to cultivate these media with relative concern and diplomacy. By contrast national journalists attending on the battlebus felt they got little for their expensive tickets and were annoyed by their perceived lack of access to Blair and his campaign. In an election campaign marked by perceived voter disengagement the party privileged regional and local media as potentially fruitful avenues to reach an apparently bored public.

\section{Conclusions}

Martin Harrop and has termed the 2001 general election the 'apathetic landslide'. That said Harrop points to three particular legacies of this most predictable campaign, namely the debate over Labour's plans for public service provision, the striking decline in electoral voter turnout, and the marked bias in the electoral system towards the governing party. In past elections these factors might have most damaged Labour's electoral prospects. This was not the case in 2001. If the electoral system worked against the Conservatives they were virtually sidelined during the debate over Tony Blair's defence of public-private partnerships in the delivery of government services. Here the most telling critiques came from government sympathisers. Even the serious decline in (disproportionately Labour) voter participation failed to harm the party's prospects. This may not be the case in the future. 
The growing marketing colonisation of modern campaigning has had a major impact on political life and, in particular, Labour. It is perhaps ironic that, at the very same time that the party has been one of the most committed to spending more time and resources on understanding the public, voters are less likely to participate in elections. That said political marketing techniques are less about understanding the electorate as a whole and more about cultivating and maintaining support within key segments of the populace. Thus parties use of such methods for their own strategic ends can and does often conflict with the goals of fostering a healthy democratic debate and maximising electoral participation. Though Labour ultimately triumphed at the election, Millbank's Operation Turnout was neither a success in terms of mobilising core supporters nor capturing the public imagination. In the absence of an effective opposition the party won the campaign almost by default. That said the real challenge of convincing the electorate of government plans may now begin.

\section{References.}

Cook, G. (2001) 'The Labour Campaign', paper presented to the UK Political Studies Association Elections Public Opinion and Parties Group Conference on the General Election, Sussex University, September.

Denver, D. (1994) Elections and Voting Behaviour. London: Harvester Wheatsheaf.

Denver, D. and Hands, G. (1997) Modern Constituency Electioneering. London: Frank Cass. 
Denver, D., Hands, G. and Fisher, J. (2001) 'Constituency Campaigning in the 2001 General Election', paper presented to the UK Political Studies Association Elections Public Opinion and Parties Group Conference on the General Election, Sussex University, September.

Dilnot, A. (2001) 'Our Unequal Society', The Guardian, $2^{\text {nd }}$ June.

Foley, M. (2000) The British Presidency: Tony Blair and the Politics of Public Leadership. Manchester, Manchester University Press.

Franklin, R. (1994), Packaging Politics: Political Communications in Britain's Media Democrac. London, Edward Arnold.

Freedland, J. (2001) 'Labour listens and learns from Gore's great mistake', The Guardian, $4^{\text {th }}$ June.

Gamble, A. (1974), The Conservative Nation, London, Routledge Kegan and Paul.

Gould, P. (1998) The Unfinished Revolution: How the Modernisers Saved the Labour Party. London: Little Brown.

Gould, P. (2001) 'The Labour Strategy', paper presented to the UK Political Studies Association Elections Public Opinion and Parties Group Conference on the General Election, Sussex University, September.

Harrop, M. (2001) An Apathetic Landslide: The British General Election of 2001, Government and Opposition, 63, pp.295-313.

Harrop, M. and Shaw, A. (1989), Can Labour Win? London: Unwin.

Hunt, S.D. (1976), "The Nature and Scope of Marketing", Journal of Marketing, 40, pp.17-28.

Jones, N. (1995), Soundbites and Spin Doctors: How politicians manipulate the media and vice versa, London, Cassell. 
Lister, R. (2001) 'Social cost of the Middle England ethos', The Guardian, $25^{\text {th }}$ May.

Mughan, A. (2000) Media and the Presidentialization of Parliamentary Elections. Basingstoke: Palgrave.

Niffenegger, P. (1989), Strategies for success from the political marketers, Journal of Consumer Marketing, 6, pp. 45-51.

Powell, C. (2001) 'Time for a little old style fervour', The Observer, $20^{\text {th }}$ May. Schumpeter, J. (1943), Capitalism, Socialism and Democracy, London, Urwin.

Seyd, P. (2001) 'The Labour Campaign', in Norris, P. (ed.) Britain Votes 2001. Oxford: Oxford University Press.

Travis, A. and Maguire, K. (2001) 'The not-so-hidden persuaders', The Guardian, $15^{\text {th }}$ May.

Wintour, P. (2001) 'Brown's round table generals draw up battle plans', The Guardian, $13^{\text {th }}$ March.

Worcester, R. (1991), British Public Opinion, Oxford, Blackwell.

Wring, D. (1997) Reconciling Marketing with Political Science: Theories of Political Marketing, Journal of Marketing Management, 13:7, pp.651-663.

Wring, D. (1999) 'The Marketing Colonisation of Political Campaigning', in Newman, B.(ed.) Handbook of Political Marketing. London: Sage.

Wring, D. (2001) 'The Tony Press: Media Coverage of the Election Campaign', in Geddes, A. and Tonge, J. (eds) Labour's Second Landslide: The British General Election of 2001. Manchester: Manchester University Press. 